\title{
Perlindungan Homeworker Yang Berkerja Secara Putting Out System
}

\author{
Solechan \\ Fakultas Hukum, Universitas Diponegoro \\ Solechan@undip.ac.id
}

\begin{abstract}
This study aims to describe the homeworker protection that works on the putting out system. The results of the study indicate that homeworker protection working in a putting out system has not been fully implemented. This can be seen in the bell: there are rules that specifically protect homeworkers working in the putting out system.
\end{abstract}

Keywords: Homeworkers, Putting Out System, Legal Protection

Abstrak

Penelitian ini bertujuan untuk menguraikan perlindungan homeworker yang berkerja secara putting out system. Hasil penelitian menujukan bahwa perlindungan homeworker yang berkerja secara putting out system belum sepenuhnya dilakukan. Hal tersebut dapat dilihat bel;um adanya aturan yang secara khusus melindungi pekerja rumahan yang bekerjas secara putting out system.

Kata Kunci: Homeworkers, Putting Out System, Perlindungan Hukum

\section{A. Pendahuluan}

Di Indonesia, ada 3 kategori pekerja rumahan yaitu pekerja rumahan yang dilakukan secara mandiri, dimana proses produksi dilakukan dan ditujukkan untuk kepentingan pribadi. Kedua, pekerja rumahan yang bertindak sebagai middle persons atau dalam kata lain majikan memperkerjakan orang lain berikut memperkerjakan dirinya dalam sebuah usaha di sebuah rumah atau lokasi dan ketiga, pekerja rumahan yang bekerja secara Putting Out System (POS) dimana para pekerja membawa pekerjaanya ke rumah masing-masing dan dibayar berdasarkan target kerja, seperti jumlah produk yang mampu dihasilkannya. ${ }^{1}$

Keberadaan pekerja rumahan yang bekerja secara Putting Out System masih bersifat invisible, sehingga menyebabkan kondisi kerjanya masih di bawah standar kondisi

\footnotetext{
${ }^{1}$ Agung Sudrajat, "Putting Out System (POS): Secarik Analisis Resiko Kesehatan dan Keselamatan Kerja" https://soedradjat.wordpress.com/2010/09/19/"putting-out-system-pos-secarik-analisis-resiko-kesehatandan-keselamatan-kerja/, diakses pada tanggal 5 November 2018.
} 
kerja pekerja formal. Ada banyak persoalan yang sering dihadapi oleh pekerja rumahan ini, diantaranya tidak adanya perjanjian kerja tertulis (kontrak kerja), upah di bawah UMR, jam kerja panjang, tidak ada jaminan sosial, jaminan pendapatan, jaminan kesehatan dan keselematan kerja, tidak mengenal cuti dan libur, bahkan ada yang selama proses produksi pekerja rumahan tersebut juga ikut menanggung ongkos biaya serta belum ada perlindungan hukum yang jelas sehingga tidak ada mekanisme untuk penyelesaian perselisihan. Kondisi tersebut sampai saat ini masih dialami dan dihadapi oleh sebagian besar pekerja rumahan di Indonesia. Sehingga pekerja rumahan berada pada posisi yang rentan dan dekat dengan garis kemiskinan, serta hak-hak dasar sebagai pekerja tidak terlindungi, terjamin, dan terpenuhi.

Putting out system sendiri pada dasarnya adalah bentuk ganda dari ibu rumah tangga yang mayoritas merupakan masyarakat menengah ke-bawah. Pekerja yang bekerja dengan sistem ini dibayar berdasarkan jumlah barang yang diproduksi oleh si pekerja bukan berdasarkan jam kerja. Selain itu, majikan hanya memberikan material pendukung tanpa ada perlindungan berupa alat pelindung diri ataupun jaminan sosial yang diberikan kepada pekerja. Kondisi tersebut lebih diperparah dengan keterlibatan sanak keluarga juga anak-anak dengan dalih untuk mempercepat pekerjaan padahal secara hukum tidak dibenarkan mempkerkerjakan anak-anak tanpa ada aturan khusus sesuai dengan UndangUndang No. 13 tahun 2003 tentang Ketenagakerjaan bab 10 paragraf 2 pasal 68. Dengan demikian dapat diasumsikan resiko kecelakaan kerja untuk para pekerja yang bekerja secara putting out system cukup besar apalagi ditambah ligkungan rumah semakin tidak sehat karena para pekerja berasal dari ekonomi bawah.

Di Jawa Tengah setidaknya terdapat 6.500 orang pekerja rumahan antara lain tersebar di Kabupaten Semarang sekitar 3.000 orang yang dipekerjakan 810 perusahaan, di Kota Semarang ada sekitar 300 orang yang dipekerjakan 6 perusahaan. Kemudian di Kota Pekalongan ada sekitar 2.500 orang yang dipekerjakan oleh beberapa perusahaan tekstil, di Kota Surakarta dan Kabupaten Sukoharjo ada sekitar 500 buruh rumahan serta Kabupaten Batang ada 1.000 orang yang dipekerjakan perusahaan garmen, tekstil, dan jenis perusahaan lain. $^{2}$

\footnotetext{
${ }^{2}$ M Nur Huda, "Pekerja Rumahan Tuntut Hak Sebagai Buruh", http://jateng.tribunnews.com/2015/12/14/pekerja-rumahan-tuntut-hak-sebagai-buruh, diakses pada tanggal 28 November 2018.
} 
Dari data diatas dapat kita lihat banyak pekerja rumahan yang terdapat di Jawa Tengah tetapi belum ada pengaturan khusus mengenai pekerja rumahan itu sendiri. Bahkan peraturan perundang-undangan ketenagakerjaan belum mampu menjangkau secara eksplisit pekerja dalam ranah putting out system. Dampaknya adalah mereka yang menggunakan sistem ini tidak dapat diakomodasi kepentingannya secara langsung oleh pemerintah/negara.

\section{B. Pembahasan}

\section{Dasar Hukum Perlindungan bagi Pekerja}

Menururt Imam Soepomo, perlindungan tenaga kerja dibagi menjadi tiga macam $^{3}$, yaitu: a). Perlindungan ekonomis, yaitu suatu jenis perlindungan yang berkaitan dengan usaha-usaha untuk memberikan kepada pekerja suatu penghasilan yang cukup memenuhi keperluan sehari-hari baginya beserta keluarganya termasuk dalam hal pekerja tersebut tidak mampu bekerja karena sesuatu di luar kehendaknya. Perlindungan ini disebut dengan jaminan social; b). perlindungan sosial, yaitu suatu perlindungan yang berkaitan dengan usaha kemasyarakatan, yang tujuannya memungkinkan pekerja itu mengenyam dan memperkembangkan perikehidupannya sebagai manusia pada umumnya, dan sebagai anggota masyarakat dan anggota keluarga. Perlindungan ini disebut kesehatan kerja; c). Perlindungan teknis, yaitu suatu jenis perlindungan yang berkaitan dengan usaha-usaha untuk menjaga pekerja dari bahaya kecelakaan yang dapat ditimbulkan oleh pesawat-pesawat atau alat kerja lainnya atau oleh bahan yang diolah atau dikerjakan perusahaan. Perlindungan ini disebut dengan keselamatan kerja.

Perlindungan pekerja mutlak harus dipahami dan dilaksanakan sebaik-baiknya oleh pengusaha sebagai pemberi kerja karena bertujuan untuk menjamin berlangsungnya sistem hubungan kerja secara harmonis tanpa disertai adanya tekanan dari pihak yang kuat kepada pihak yang lemah. Untuk ini pengusaha wajib melaksanakan ketentuan perlindungan tersebut sesuai peraturan perundang-undangan yang berlaku Jika pengusaha melakukan pelanggaran maka dikenakan sanksi. ${ }^{4}$

\section{Karateristik Pekerja Rumahan Yang Bekerja Dengan Cara Putting Out System}

Pekerja rumahan adalah bagian dari Putting Out System. Pekerja rumahan tidak dijabarkan dalam undang-undang atau peraturan nasional di Indonesia. Untuk tujuan analisis, definisi pekerja rumahan yang diberikan oleh Konvensi ILO tahun 1977 No. 177 tentang Kerja Rumahan, yaitu "seseorang yang melakukan pekerjaan di dalam rumahnya

\footnotetext{
${ }^{3}$ Abdul Khakim, Op.cit, hlm.61.

${ }^{4}$ Abdul Khakim, Op.cit, hlm. 62
} 
atau di tempat lain sesuai dengan pilihannya selain dari tempat kerja pemberi kerja; untuk pengupahan yang didapatkan dari hasil produk atau jasa yang diinginkan oleh pemberi kerja, tanpa melihat siapa yang menyediakan peralatan, bahan atau hal lain yang digunakan"5. Definisi pekerja rumahan ini mencakup unsur-unsur umum sebuah hubungan kerja-pekerjaan, upah dan tingkat subordinasi yang ditentukan. Dalam konteks Indonesia, keberadaan unsur-unsur hubungan kerja ini menentukan tingkat cakupan undang-undang ketenagakerjaan nasional. 'Pekerja rumahan' harus terikat dalam sebuah hubungan kerja untuk mendapakan perlindungan hukum. Mengingat biasanya tidak ada pengawasan langsung oleh pemberi kerja atau kontraktor terhadap ketenagakerjaan dan kontribusi pekerja rumahan terhadap proses produksi, maka kurang adanya pemahaman umum di kalangan pejabat pemerintah di tingkat lokal maupun pengusaha dan pekerja tentang hubungan dan tanggung jawab pemberi kerja terhadap pekerja rumahan di Indonesia.

Konvensi ILO tentang Kerja Rumahan membedakan pekerja rumahan dari kategori pekerja lain yang melakukan pekerjaan di tempat selain tempat kerja milik pemberi kerja. Orang-orang ini yang memiliki tingkat otonomi atau/dan kemandirian ekonomi dianggap sebagai seorang pekerja yang mandiri (pekerja mandiri atau pekerja yang memiliki usaha sendiri di rumah) dan yang kedua, para pekerja yang "terkadang melakukan pekerjaan mereka sebagai pegawai di rumah dan bukan di tempat kerja mereka” tidak dianggap sebagai pekerja rumahan menurut Konvensi ini.

Putting Out System adalah sistem untuk mengatur, mengendalikan dan memobilisasi proses produksi dan hubungan produksi dari bahan mentah menjadi barang jadi yang dilakukan di luar perusahaan. Pekerjaan dari perusahaan dan dikerjakan oleh pekerja yang dipilih sendiri, biasanya di rumah pekerja atau disekitar rumah pekerja. Dalam sistem ini, pekerja dikategorikan sebagai pekerja rumahan yaitu, tenaga kerja yang menerima pekerjaan dari pengusaha tanpa ikatan kerja formal, membawa dan mengerjakannya dirumah, tanpa supervisi, menyediakan sendiri fasilitas kerja, menanggung sendiri resiko produksi serta menerima upah kerja berdasarkan output satuan (borongan) menurut ukuran sang pengusaha. ${ }^{6}$

Kurangnya pengakuan hukum yang eksplisit terhadap pekerja rumahan sebagai kategori pekerja khusus di dalam undang-undang dan peraturan Indonesia juga tercermin

\footnotetext{
${ }^{5}$ Konvensi ILO tentang Kerja Rumahan, 1996 (No.177), Pasal 1.

${ }^{6}$ Ken Surtiyah, Pengorbanan Wanita Pekerja Industri dalam Sangkan Paran Gender, (Yogyakarta: Pustaka Pelajar, 1997), hlm. 224-225
} 
dalam langkanya data statistik nasional tentang pekerja rumahan. Statistik angkatan kerja nasional (Sakenas) saat ini tidak mampu mengidentifikasi pekerja rumahan atau pekerja berbasis rumahan di Indonesia. Praktik kerja rumahan juga tidak mampu ditangkap oleh instrumen survei industri atau sektor tertentu. 'Ketidakterlihatan' kerja rumahan di dalam undang-undang dan statistik ketenagakerjaan nasional ini mencerminkan sifat informal dan tak terlihatnya kerja rumahan di Indonesia.

Mengikuti definisi pekerja rumahan sebagaimana yang ditetapkan oleh Konvensi ILO tentang Kerja Rumahan (No.177), pekerja rumahan di Indonesia adalah para pekerja yang bekerja di rumah atau komunitas mereka sebagai bagian dari putting out system industrial. Para pekerja ini terikat dalam hubungan kerja dengan para pemberi kerja, atau perantara mereka, dan memberikan kontribusi pada produksi sebuah produk tertentu yang ditentukan oleh pemberi kerja.

Berbagai bentuk kerja rumahan ditemukan di Indonesia. Pekerja, yang mayoritas adalah perempuan, terlibat dalam bentuk subkontrak komersial maupun industrial. Dalam subkontrak komersial, yang sering disebut sebagai putting out system, kontraktor tidak turut serta dalam proses produksi secara nyata. Di sisi lain, dalam subkontrak industrial, kontraktor sendiri terlibat dalam proses produksi. Baik pedagang maupun produsen dapat berfungsi sebagai kontraktor. Pedagang yang mengkhususkan diri dalam pemasaran berbagai produk tertentu dapat mengatur produksi dengan mensubkontrak perusahaan atau perseorangan terpilih yang harus memproduksi sesuai dengan standar dan spesifikasi yang ditetapkan oleh kontraktor. Namun, produsen akan menggunakan subkontraktor untuk melaksanakan tugas-tugas tertentu di dalam keseluruhan proses produksi mereka.

\section{Simpulan}

Berdasarkan keseluruhan uraian tersebut diatas maka, hasil penelitian menujukan bahwa perlindungan homeworker yang berkerja secara putting out system belum sepenuhnya dilakukan. Hal tersebut dapat dilihat bel;um adanya aturan yang secara khusus melindungi pekerja rumahan yang bekerjas secara putting out system.

\section{Daftar Pustaka}

Asyhadie, Zaeni, Hukum Kerja: Hukum Ketenagakerjaan Bidang Hubungan Kerja, (Jakarta: PT RajaGrafindo Persada, 2007).

Koentjoroningrat, Metode-metode Penelitian Masyarakat, (Jakarta : Ikrar Mandiri Alam, 1993).

Koto, Alaiddin Filsafat Hukum Islam, (Jakarta: PT RajaGrafindo Persada, 2014). 
Mamudji, Sri dkk., Metode Penelitian dan Penulisan Hukum, (Jakarta: Fakultas Hukum Universitas Indonesia, 2005).

Marzuki, Metodelogi Riset, (Yogyakarta: Fakultas Ekonomi, 1983).

Marzuki, Peter Mahmud, Penelitian Hukum, (Jakarta: Kencana, 2007).

Mertokusumo, Sudikno, Mengenal Hukum (Suatu Pengantar), (Yogyakarta: Liberty, 1991).

Muhammad, Abdulkadir, Hukum dan Penelitian Hukum, (Bandung: PT Citra Aditya Bakti,2004)

Partanto, Pius dkk, Kamus Ilmiah Popular, (Surabaya: Arkola, 2001).

Rusli, Hardijan, Hukum Ketenagakerjaan 2003, (Jakarta: Ghalia Indonesia, 2004).

Sunggono, Bambang, Metodologi Penelitian Hukum, (Jakarta: PT Raja Grafindo Persada, 2003).

Sutedi, Adrian, Hukum Perburuhan, (Jakarta: Sinar Grafika, 2009).

Wijayanti, Asri, Perlindungan Hukum Bagi Buruh Indonesia, (Jakarta: PT. Bina Aksara 2003).

Subijanto, Peran Negara Dalam Hubungan Tenaga Kerja Indonesia , (Jurnal Pendidikan Dan Kebudayaan vol 17 no 6, 2011).

Undang-Undang Dasar Negara Republik Indonesia Tahun 1945

Undang-Undang No. 13 Tahun 2003 tentang Ketenagakerjaan

Konvensi ILO Nomor: 177 Tahun 1996 tentang Kerja Rumahan 